\title{
Involvement of tachykinin receptors in sensitisation to cow's milk proteins in guinea pigs
}

\author{
J Gay, J Fioramonti, R Garcia-Villar, X Emonds-Alt, L Bueno
}

\begin{abstract}
Background-There is growing evidence for a pivotal role for tachykinins in gut neuroimmune interactions. Aims-To determine whether NK1, NK2, and NK3 tachykinin receptors are involved in milk protein induced allergic sensitisation.

Methods-Eight groups of 12 DunkinHartley guinea pigs (250-300 g) were used. Four groups were sensitised to milk proteins for three weeks. During this period, these animals were injected intraperitoneally each day with NK1 (SR 140333; $0.3 \mathrm{mg} / \mathrm{kg}$ ), NK2 (SR 48968; 5 $\mathrm{mg} / \mathrm{kg}$ ), or NK3 (SR 142801; $5 \mathrm{mg} / \mathrm{kg}$ ) receptor antagonist or vehicle. The fifth group had water available instead of milk and was used as a non-sensitised control. The three other groups received the NK receptor antagonists for three weeks but were not sensitised to milk proteins.

Results-Sensitised animals treated with NK1 and NK3 receptor antagonists had both lower IgE and IgG serum titres, evaluated by passive cutaneous anaphylaxis, and lower specific IgG serum titres, determined by enzyme linked immunosorbent assay (ELISA), than vehicle treated animals. Sensitisation induced an increase in intestinal mast cell number which was abolished by treatment with the NK1 receptor antagonist. Antigenic challenge-induced jejunal hypersecretion was also blocked by treatment with the NK1 receptor antagonist.

Conclusion-In guinea pigs, NK1 and NK3 but not NK2 receptors are involved in sensitisation to cow's milk. However, NK1 but not NK3 receptor antagonists abolish both the hypermastocytosis induced by food allergy and the hypersecretion induced by antigenic challenge, suggesting different roles for NK1 and NK3 receptors in the mechanisms of sensitisation to B-lactoglobulin.

(Gut 1999;44:497-503)
\end{abstract}

Keywords: NK receptors; tachykinins; food allergy; $\beta$-lactoglobulin sensitisation; sensitisation; guinea pig

Sanofi Recherche, 37 rue du Pr J Blayac, 34184 Montpellier, France

$\mathrm{X}$ Emonds-Alt

Correspondence to: Dr Jean Fioramonti, INRA Department of Pharmacology, BP 3 , F-31931 Toulouse, France.

Accepted for publication 21 October 1998

Immediate hypersensitivity reactions of food allergy induce clinical manifestations, such as rhinitis, urticaria, and eczema, and gastrointestinal symptoms, such as nausea, vomiting, abdominal pain, and diarrhoea. ${ }^{1}$ These hypersensitivity reactions in sensitised subjects are a consequence of antigen exposure resulting in IgE production and attachment to mast cells.
Subsequent exposure to the antigen induces mast cell degranulation with release of stored and newly formed mediators. ${ }^{2}$ Furthermore, a close apposition between mast cells and nerves has been described in the gastrointestinal mucosa, ${ }^{3}$ and increasing evidence is emerging for nerve involvement in mast cell degranulation and induction of digestive disturbances by antigen challenge. For example, mast cell degranulation was induced by a Pavlovian reflex in egg albumin sensitised rats, ${ }^{4}$ and the neurotoxin tetrodotoxin was reported to inhibit the increase in intestinal permeability induced by egg albumin challenge in sensitised rats. ${ }^{5}$ Moreover, substance $\mathrm{P}(\mathrm{SP})$ and calcitonin gene related peptide immunoreactivities have been found in nerves apposed to mast cells, ${ }^{6}$ and motor $^{7}$ or secretory ${ }^{8}$ alterations induced by antigen challenge were reduced by destruction of afferent nerves by capsaicin or administration of an SP receptor antagonist. ${ }^{7}$

Tachykinins are a group of neuropeptides that includes SP, neurokinin A (NKA), neurokinin $\mathrm{B}(\mathrm{NKB})$, and two N-terminally extended forms of NKA, neuropeptide $\gamma$ and neuropeptide K. SP, NKA, and NKB bind preferentially to NK1, NK2, and NK3 tachykinin receptors respectively. ${ }^{9} \mathrm{SP}$ and NKA have been described in capsaicin sensitive afferent neurons among other neuromediators such as calcitonin gene related protein. ${ }^{10}{ }^{11} \mathrm{NK} 3$ receptors have been found localised in myenteric and submucosal neurons. ${ }^{12}{ }^{13}$ Besides this neuronal localisation of tachykinins and their receptors, in agreement with the neurally mediated effects of antigen challenge, tachykinins are considered to be prominent peptides in neuroimmune connections ${ }^{14}$ and especially involved in the control of immune cells that contribute to protein sensitisation and IgE synthesis. For example, SP stimulates proliferation of $\mathrm{B}$ and $\mathrm{T}$ lymphocytes ${ }^{15}$ and their immunoglobulin synthesis, or regulates cytokine production by macrophages. ${ }^{16}$ Moreover, SP levels may characterise allergies besides food allergy. Indeed even in the absence of allergen provocation, SP levels are increased in bronchoalveolar and nasal lavages of grass pollen allergy patients, in comparison with healthy subjects, ${ }^{17}$ and in nasal secretion, they reflect the clinical state of nasal allergy. ${ }^{18}$

The aim of this work was therefore to deterWe determined the effect of NK1, NK2, and $\mathrm{NK} 3$ receptors on $\mathrm{IgE}$ and $\operatorname{IgG}$ synthesis, the

Abbreviations used in this paper: $\mathrm{P}$, substance $\mathrm{P}$; NK, neurokinin; PCA, passive cutaneous anaphylaxis; ELISA, enzyme linked immunosorbent assay. 
number of mast cells, and secretory response to antigen challenge, which characterise the degree of sensitisation to cow's milk proteins in guinea pigs. The animals were treated with the selective NK1, NK2, and NK3 receptor antagonists, SR 140333, SR 48968, and SR $142801^{19-21}$ respectively during the three week period of sensitisation.

\section{Methods}

ANIMALS AND SENSITISATION

Eight groups of 12 female Dunkin-Hartley guinea pigs weighing 250-300 g (Harlan, Gannat, France) were used for these experiments. A milk protein-free solid pellet diet was supplied to all animals. Four groups were sensitised to cow's milk proteins by giving them only fresh pasteurised whole cow's milk to drink instead of water for three weeks. ${ }^{22}$ These animals received in addition a daily gavage of $100 \mathrm{mg}$ of a mixture of whey proteins enriched with $\beta$-lactoglobulin (LCL 90; Nutrinov, Rennes, France) dissolved in $1 \mathrm{ml}$ distilled water and were allowed to drink water for three days before assessment of sensitisation. Three groups received a daily treatment for the three weeks of sensitisation, by intraperitoneal injection, with tachykinin receptor antagonists (Sanofi Recherche): NK1 receptor antagonist (SR 140333; $0.3 \mathrm{mg} / \mathrm{kg}$ ), NK2 receptor antagonist (SR 48968; $5 \mathrm{mg} / \mathrm{kg}$ ), NK3 receptor antagonist (SR $142801 ; 5 \mathrm{mg} / \mathrm{kg}$ ) respectively. The doses chosen had been used in several studies and a previous in vivo model: SR 140333 at $0.3 \mathrm{mg} / \mathrm{kg} /$ day, intraperitoneally, ${ }^{23}$ SR 48968 at $5 \mathrm{mg} / \mathrm{kg} /$ day, intraperitoneally, ${ }^{24}$ and SR 142801 at $1-10 \mathrm{mg} / \mathrm{kg} /$ day, intraperitoneally. ${ }^{25}$ At these doses, the NK antagonists are specific for their receptor subtypes. ${ }^{19-21}$ The fourth group received a daily treatment with vehicle $(0.9 \% \mathrm{NaCl} /$ dimethyl sulphoxide; $1: 1 ; 0.5 \mathrm{ml}$ intraperitoneally). The fifth group drank tap water instead of milk and was considered to be a non-sensitised control. Three other groups received the NK receptor antagonists but were not sensitised to milk proteins.

\section{ANTIBODY TITRES}

Blood was withdrawn by cardiac puncture from all animals to determine anti- $\beta$ lactoglobulin IgG and IgE titres by the passive cutaneous anaphylaxis (PCA) test. Briefly, 100 $\mu \mathrm{l}$ of diluted serum ranging from 1:2 to $1: 256$ was injected intradermally into the shaved flanks of naive guinea pigs. Two days later, 2.5 $\mathrm{mg} \beta$-lactoglobulin in Evans blue dye $(1 \%$ in $0.9 \% \mathrm{NaCl}$ solution) was injected intravenously in a final volume of $0.5 \mathrm{ml}$. One hour later, PCA reactivity was measured as the highest dilution yielding a positive response (local skin turning blue in patches of diameter $>4$ $\mathrm{mm}$ ). Titres were expressed as the $\log$ of the highest dilution giving blue patches.

IgG antibodies to $\beta$-lactoglobulin were also evaluated in the serum samples by enzyme linked immunosorbent assay (ELISA). Multiwell microtitre plates were coated with $100 \mu \mathrm{l}$ $\beta$-lactoglobulin (200 ng/well). Diluted sera (1:30 to $1: 21870$ ) were added to each well.
After incubation, rat anti-guinea pig IgG peroxidase conjugate (Nordic Immunology, Tillburg, The Netherlands) was added. Peroxidase activity was assayed by staining with diamino-orthophenylene in $0.05 \mathrm{~mol} / 1$ citrate buffer $(\mathrm{pH} 4)$ containing $0.1 \% \mathrm{H}_{2} \mathrm{O}_{2}$. The reaction was stopped with $3 \mathrm{M} \mathrm{H}_{2} \mathrm{SO}_{4}$, and absorbance was measured at $492 \mathrm{~nm}$ with a microplate reader (EL 132; Bio-Tek Instruments, Winooski, VT, USA). Positive titres were given as the log of the last dilution with an absorbance that was twice that of the background.

MAST CELL NUMBER

Four days after cardiac puncture, six animals from each group were killed by cervical dislocation and exsanguination. Small pieces (5 $\mathrm{mm}$ ) of jejunum, $20 \mathrm{~cm}$ distal to the ligament of Treitz, were fixed in Carnoy's solution, cleared in toluene, and embedded in paraffin blocks. Transverse sections $(4 \mu \mathrm{m})$ were stained with alcian blue-safranin $\mathrm{O}$ for identification of intestinal mast cells, in both the mucosa and submucosa. Three sections per animal and three views per section were examined for mast cell counts. The sections were examined in a blind fashion by a person who was unaware of the experimental groups.

\section{EVALUATION OF ANTIGEN INDUCED JEJUNAL} SECRETION

Modification of intestinal transport of water is a characteristic feature of intestinal anaphylaxis. ${ }^{26}$ To assess the response to antigen challenge, we measured the net water flux of an isolated jejunal loop. ${ }^{27} \mathrm{~A}$ midline laparotomy was performed in anaesthetised (urethane, 2 $\mathrm{g} / \mathrm{kg}$ intraperitoneally) guinea pigs to expose the small intestine. A $5 \mathrm{~cm}$ segment of the distal jejunum $(30 \mathrm{~cm}$ from the ileocaecal junction) was isolated and cannulated for intraluminal perfusion. After cleansing of the intraluminal contents, the loop was replaced in the abdominal cavity, which was then closed, and the jejunal segment was infused with a Ringer buffer solution containing $1 \mu \mathrm{Ci} /{ }^{51} \mathrm{Cr}-$ EDTA as a non-absorbed dilution marker of water flux. ${ }^{28}$ The loop was infused at a constant rate $(6 \mathrm{ml} / \mathrm{h})$ and the effluent was collected for 15 minute periods $(1.5 \mathrm{ml})$ over 210 minutes $(21 \mathrm{ml})$. Total recovery of the probe ${ }^{51} \mathrm{Cr}-$ EDTA varied between 94 and 102\%. After an equilibration period (90 minutes), antigen challenge was performed by adding $\beta$-lactoglobulin $(100 \mathrm{mg})$ to the Ringer solution. Antigen was infused for 30 minutes. ${ }^{51} \mathrm{Cr}$ activity in collected samples was measured in a $\gamma$ counter (Cobra II; Packard, Meriden, CT, USA), and water flux for every 15 minute period was calculated using the following formula: net water flux $(\mu \mathrm{l} / \mathrm{cm} / \mathrm{h})=\left(1-\left(\mathrm{cpm}_{\mathrm{s}} /\right.\right.$ $\left.\left.\mathrm{cpm}_{\mathrm{x}}\right)\right) \times(\mathrm{P} / \mathrm{L})$, where $\mathrm{cpm}_{\mathrm{s}}$ and $\mathrm{cpm}_{\mathrm{x}}$ are ${ }^{51} \mathrm{Cr}$ radioactivity in Ringer solution and effluent respectively, $P$ is the perfusion rate $(\mu 1 / h)$, and $L$ the length $(\mathrm{cm})$ of jejunal segment. Positive values represent net absorption of water, and negative values represent net secretion. 


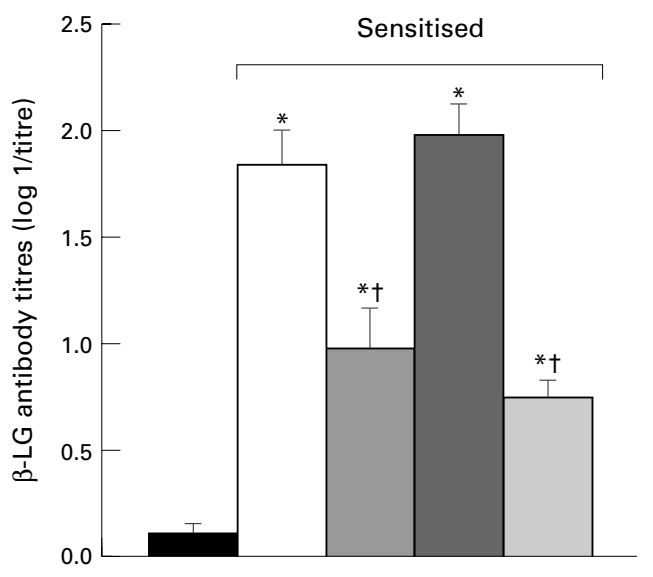

Non-sensitised controls

Sensitised controls

SR 140333 (0.3 mg/kg/day; ip)

SR 48968 ( 5 mg/kg/day; ip)

SR 142801 (5 mg/kg/day; ip)

Figure 1 Antibodies to $\beta$-lactoglobulin $(\beta-L G)$ evaluated by passive cutaneous anaphylaxis test in non-sensitised and sensitised controls and in sensitised guinea pigs treated for three weeks with NK1 (SR 140333), NK2 (SR 48968) or NK3 (SR 142801) receptor antagonist. * Significantly different $(p<0.05)$ from non-sensitised controls $(n=12)$; tsignificantly different $(p<0.05)$ from sensitised controls ( $n$ =12).

DRUGS

The drugs used in this study were: SR 48968 $((S)$-N-methyl-[4-acetylamino-4-phenyl piperidin-2-(3,4)dichlorophenyl)butyl] benzamide) (saredutant) used as hydrochloride; SR 40333 ((S)1-\{2-[3-(3,4-dichlorophenyl)-1-(3-isopropoxyphenylacetyl)piperidin-3-yl] ethyl $\}$-4-phenyl-1-azoniabicyclo [2.2.2] octane chloride] (chloride of nolpitantium); SR $142801((R)$ -(N)-(1-\{3-(1-benzoyl-3-(3,4-dichlorophenyl) piperidin-3-yl)propyl $\}$-4-phenylpiperidin-4-yl)$\mathrm{N}$-methylacetamide) (osanetant) used as hydrochloride. They were synthesised by Sanofi Recherche and dissolved in saline containing $50 \%$ (v/v) dimethyl sulphoxide.

STATISTICAL ANALYSIS

Values of PCA titres, mast cell number, and antigen induced jejunal secretion were compared after analysis of variance, using Student's unpaired $t$ test or the Mann-Whitney test for unpaired values. Results are expressed as mean (SEM), and differences were considered significant for $\mathrm{p}<0.05$.

\section{Results}

SENSITISATION RATE

No positive response was detected by the PCA test in non-sensitised guinea pigs and in non-sensitised animals treated with NK receptor antagonists. In sensitised animals treated with vehicle, the PCA titres reached 1.84 (0.16). In sensitised animals treated with NK1 or NK3 receptor antagonist, the titres were significantly $(\mathrm{p}<0.01)$ lower $(0.98(0.18)$ and 0.75 (0.08) respectively). The titre was not signifi-

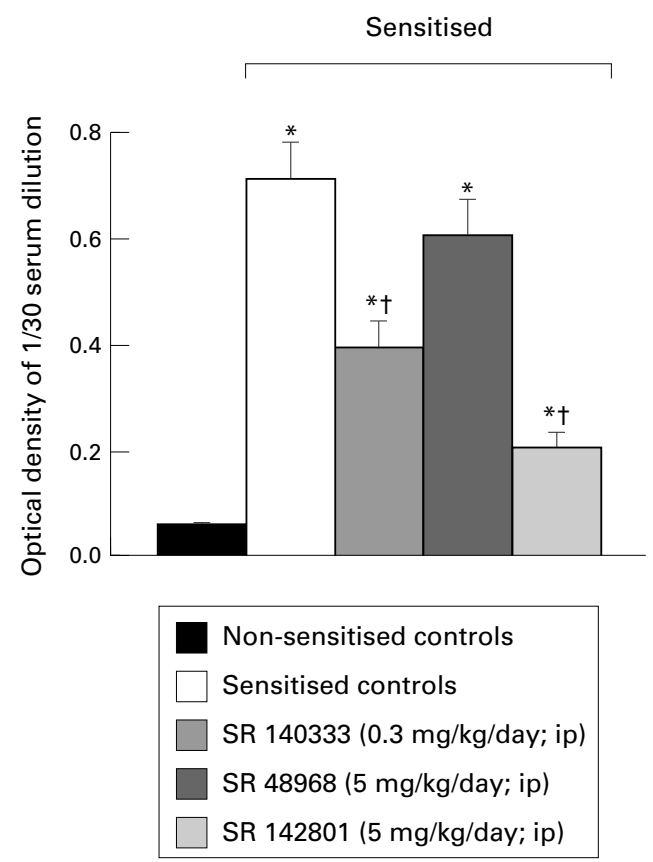

Figure 2 Effect of three weeks of treatment with NK1, $N K 2$, or NK3 receptor antagonist on anti- $\beta$-lactoglobulin IgG antibody titres. * Significantly different $(p<0.05)$ from non-sensitised controls $(n=12)$; †significantly different $(p<0.05)$ from sensitised controls $(n=12)$.

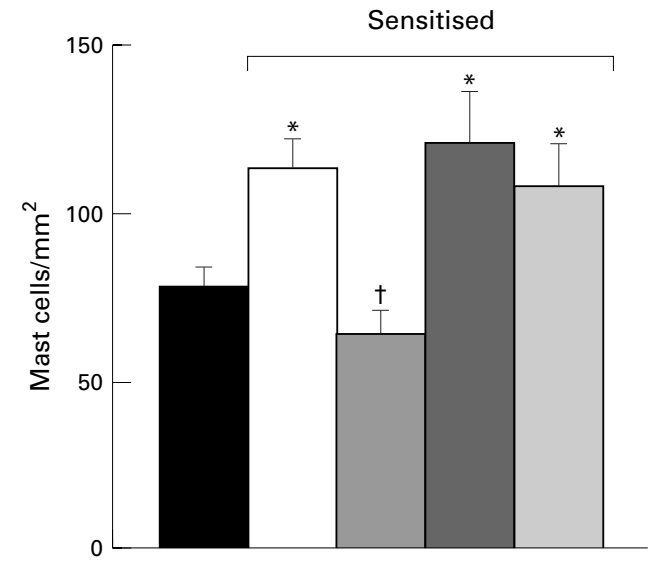

Non-sensitised controls

Sensitised controls

SR 140333 (0.3 mg/kg/day; ip)

SR 48968 (5 mg/kg/day; ip)

SR 142801 (5 mg/kg/day; ip)

Figure 3 Number of mast cells in jejunal sections of non-sensitised and sensitised controls and sensitised animals treated for three weeks with NK1, NK2, or NK3 receptor antagonist. ${ }^{\star S i g n i f i c a n t l y ~ d i f f e r e n t ~}(p<0.05)$ from non-sensitised controls $(n=6)$; †significantly different $(p<0.05)$ from sensitised controls $(n=6)$.

cantly ( $p>0.05)$ modified (1.98 (0.15)) in animals treated with the NK2 receptor antagonist (fig 1).

The anti $\beta$-lactoglobulin IgG titre disclosed by ELISA and expressed as absorbance obtained for a 1:30 diluted serum was not detectable in the non-sensitised controls. The titre was $0.71(0.07)$ in sensitised animals treated with vehicle. It was significantly $(\mathrm{p}<0.05)$ lower 

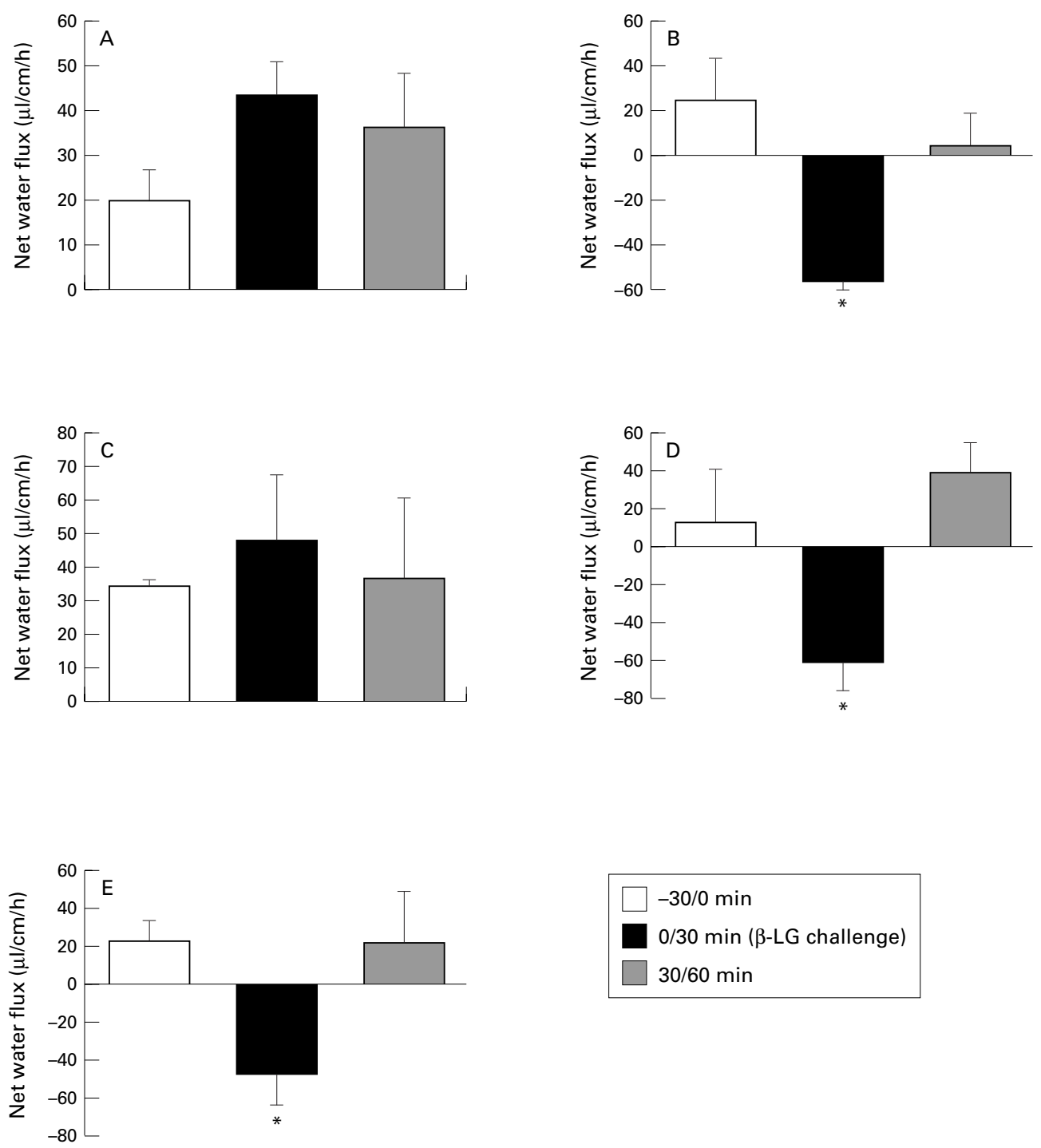

Figure 4 Effect of intrajejunal infusion of $\beta$-lactoglobulin on jejunal net water flux in $(A)$ non-sensitised and $(B)$ sensitised controls and in guinea pigs treated for three weeks with (C) NK1, (D) NK2 or (E) NK3 receptor antagonist. *Significantly different $(p<0.05)$ from non-sensitised controls for the same period $(n=6)$.

in sensitised animals treated with the NK1 and NK3 receptor antagonists $(0.39(0.05)$ and 0.20 (0.03) respectively) but was not significantly $(\mathrm{p}>0.05)$ modified by $\mathrm{NK} 2$ receptor antagonist treatment $(0.59(0.07))$ (fig 2$)$.

JEJUNAL MAST CELLS

The number of mast cells $/ \mathrm{mm}^{2}$ of jejunum was significantly $(\mathrm{p}<0.05)$ increased in sensitised animals (113.3 (9.2)) in comparison with nonsensitised animals (78.1 (6.2)) or nonsensitised animals treated with NK1, NK2, or NK3 receptor antagonists (75.4 (5.3), 82.6 (3.5), and 73.7 (6.1) respectively). NK1 receptor antagonist abolished the increase in number of mast cells induced by the sensitisation (64.2 (6.7)). However, the number of mast cells was not significantly ( $p>0.05)$ modified by treatment with NK2 or NK3 receptor antagonist in sensitised guinea pigs (120.7 (15.6) and 107.8 (12.8) respectively) (fig 3 ).
JEJUNAL SECRETION AFTER ANTIGENIC

CHALLENGE

Infusion of $\beta$-lactoglobulin (100 mg) in sensitised animals reversed the net water flux of the jejunal loop from an absorptive to a secretory state. This change did not occur in nonsensitised animals and in non-sensitised animals treated with the NK1, NK2, or NK3 receptor antagonists. In these, water absorption was constant throughout the time course of the study. Basal net water flux in sensitised animals was $24(19) \mu \mathrm{l} / \mathrm{cm} / \mathrm{h}$ during the 30 minutes preceding the antigenic challenge. During the intrajejunal perfusion of $\beta$-lactoglobulin over 30 minutes, a net secretion of water, reaching -55 (4) $\mu \mathrm{l} / \mathrm{cm} / \mathrm{h}$, was observed. After $\beta$-lactoglobulin challenge, the net water absorption was restored and values after infusion were not significantly different from basal values. In sensitised animals treated with the NK1 receptor antagonist, the antigenic challenge did not induce hypersecretion (49.5 
(20.5) $\mu \mathrm{l} / \mathrm{cm} / \mathrm{h}$ ). The challenge induced hypersecretion was not significantly $(p>0.05)$ modified by treatment with $\mathrm{NK} 2$ or NK3 receptor antagonist (-59.5 (16.5) and -46 (16.6) $\mu \mathrm{l} / \mathrm{cm} / \mathrm{h}$ respectively) (fig 4 ).

\section{Discussion}

Our results indicate that NK1 and NK3 tachykinin receptors are involved in the processes of oral sensitisation to $\beta$-lactoglobulin in guinea pigs. As the compounds used (SR 140333, SR 48968 , and SR 142801) are considered to be selective and potent antagonists for NK1, NK2, and NK3 receptors ${ }^{19-21}$ respectively, we can postulate that $\mathrm{SP}$ and NKB, but not NKA, play a role in this sensitisation process. The model of oral sensitisation we used has been found to induce allergic digestive disturbances similar to those found after parenteral sensitisation..$^{29}$ The oral route of sensitisation mimics what occurs in infants with cow's milk allergy diseases and therefore appears to be a clinically relevant model. However, unlike in infants with cow's milk allergy, no diarrhoea is observed in the guinea pig, but soft faeces associated with accelerated colonic transit has been described in this model. ${ }^{30}$ The PCA test is classically used to evaluate the degree of sensitisation, and intestinal fluid secretion has often been used to evaluate the intensity of anaphylaxis after antigenic challenge. ${ }^{31}{ }^{51} \mathrm{Cr}$-EDTA is generally considered to be a marker of epithelial permeability. ${ }^{32} 33$ However, its absorption is found to be very low, even in patients with inflammatory bowel disease. ${ }^{34}$ Theodorou et $a l^{28}$ have shown very low absorption of ${ }^{51} \mathrm{Cr}-\mathrm{EDTA}$, about $1-2 \%$ of the administered dose per os and excreted in the urine after $24 \mathrm{~h}$. Consequently, the amount of ${ }^{51} \mathrm{Cr}$-EDTA absorbed from the perfused $5 \mathrm{~cm}$ jejunal segment is probably not significant. Despite a report of a transient increase in jejunal permeability during challenge administration, ${ }^{55}$ we found a recovery of ${ }^{51} \mathrm{Cr}$ EDTA, calculated from the total volume of effluent collected over the experimental period, varying from 94 to $102 \%$. Moreover, we found no trace of radioactivity in blood samples taken at the end of experimentation (data not shown). In several studies of food allergy, the results of mast cell counts are controversial. In one study, in the same model of guinea pig cow's milk allergy, the authors did not find any modification of the submucosal mast cell counts in the colon due to sensitisation. ${ }^{36}$ In other studies, no clear correlation between mast cell counts and food allergy has been shown. ${ }^{57}$ However, the mast cell hyperplasia found in sensitised animals in the present study has also been described in a rat model of food allergy, ${ }^{38}$ and some studies have indicated possible relations between systemic mastocytosis and food allergy. ${ }^{39}$

Serum titres of anti- $\beta$-lactoglobulin $\operatorname{IgE}$ and IgG were reduced after treatment with the NK1 receptor antagonist SR 140333. We can postulate that SP participates in the sensitisation process by enhancing immunoglobulin synthesis by B lymphocytes. As interactions between $\mathrm{B}$ and $\mathrm{T}$ lymphocytes are known to be crucial for IgE production, ${ }^{40}$ such an hypothesis agrees with both the presence of SP receptors on B and T lymphocytes ${ }^{41}$ and the stimulation of lymphocyte proliferation by $\mathrm{SP}^{42} \mathrm{On}$ the other hand, IgE synthesis has been shown to be regulated by cytokines. For example, interleukin-4, -5 , and -6 upregulate, whereas interferon- $\gamma$ and interleukin-2 downregulate, IgE production. ${ }^{43}$ Exogenous SP has been found to stimulate interleukin- 1 and -6 and tumour necrosis factor- $\alpha$ release by monocytes. ${ }^{44}$ This effect occurs at low doses of SP and is specific, as it was blocked by an SP antagonist. Moreover, interleukin-6 is known to stimulate the growth of T lymphocytes. ${ }^{45} \mathrm{SP}$ has also been found to accentuate IgE synthesis induced by interleukin- $4 .^{46}$ Taken together, the above data favour a stimulating role for SP in $\operatorname{IgE}$ production and are in agreement with the reduction in $\operatorname{IgE}$ and $\operatorname{IgG}$ titres observed after treatment of sensitised animals with the NK1 receptor antagonist.

NKB also plays a role in antigenic sensitisation to $\beta$-lactoglobulin, as $\operatorname{IgE}$ and $\operatorname{IgG}$ titres were reduced by treatment with $\mathrm{NK} 3$ receptor antagonist. However, we have no explanation for this effect, as $\mathrm{NK} 3$ receptors have never been reported to be present on immune cells. Until now NK3 receptors in the digestive tract have been identified only on myenteric and submucosal neurons in the rat gastrointestinal tract, ${ }^{12}$ on cholinergic neurons of the myenteric plexus in the guinea pig ileum, ${ }^{47}$ and on intrinsic sensory neurons projecting into the mucosa in the rat ileum. ${ }^{13}$

We have shown that the increase in mast cell number observed in sensitised animals was abolished by treatment with the NK1 receptor antagonist. The existence of anatomic and functional contacts between amyelinic nerve fibres and mast cells is now well established, ${ }^{3}$ and suggests that bidirectional trophic interactions occur between nerves and mast cells. Mast cells influence the development of sensory neurons through the release of nerve growth factor. On the other hand, destruction by capsaicin of SP sensory neurons in neonatal rats has been found to reduce the number of intestinal mucosal mast cells. ${ }^{48}$ Moreover, several cytokines such as interleukin-3, -4, -9, and -10 and nerve growth factor promote mast cell proliferation, ${ }^{49}$ and it can be postulated that some of these cytokines are involved in proliferative actions of SP on mast cells. Nevertheless, the inhibitory action of NK1 receptor antagonist on mast cell proliferation induced by cow's milk sensitisation seems to be specifically mediated by SP and NK1 receptors, as this proliferation was not observed after $\mathrm{NK} 2$ and NK3 receptor antagonist treatment.

An interesting finding concerns the differences in the effects of NK1 and NK3 receptor antagonist treatments in sensitised animals. The NK1 receptor antagonist reduced $\operatorname{IgE}$ and IgG titres, abolished hypermastocytosis, and blocked the jejunal secretory response to antigenic challenge, whereas the NK3 receptor antagonist also reduced IgE and IgG titres but did not modify either hypermastocytosis or the anaphylactic secretory response. This may 
indicate that in food allergy, at least cow's milk allergy in guinea pigs, intestinal hypermastocytosis is perhaps a condition that induces a secretory response to the antigenic challenge. It has also been shown that the mast cell stabiliser doxantrazole suppresses challenge induced colonic secretion in cow's milk sensitised guinea pigs. ${ }^{28}$

Another explanation for the decrease in sensitisation rate after treatment with NK1 and $\mathrm{NK} 3$ receptor antagonists could be a reduction in antigen uptake. The results on intestinal permeability in the basal state or after antigen challenge in animals sensitised to cow's milk are controversial. In one study, ${ }^{50}$ a decrease in intestinal permeability was shown after four weeks of sensitisation to cow's milk. In contrast, another study ${ }^{29}$ shows an increase in intestinal permeability after three weeks of sensitisation to cow's milk. Moreover, it has been recently shown that NKA increases intestinal permeability through the activation of $\mathrm{NK} 2$ receptors, ${ }^{51}$ and we found no change in sensitisation rate after NK2 receptor antagonist treatment. Therefore there is no evidence for the action of NK1 or NK3 receptor antagonist on intestinal permeability.

It can be concluded that treatment with NK1 and NK3 receptor antagonists reduces the rate of sensitisation to oral cow's milk proteins in guinea pigs through different mechanisms, an action on intestinal hypermastocytosis and secretory response to antigen challenge being observed with the NK1 receptor antagonist whereas both $\mathrm{NK} 1$ and $\mathrm{NK} 3$ receptor antagonists reduce IgE and IgG titres.

The authors thank Colette Bétoulières and Lucien Ressayre for their skilful technical assistance. This work was supported by a research agreement INRA/Sanofi (C-9764) and was presented at the 6th United European Gastroenterology Week, October 1997, Birmingham, UK.

1 Sampson HA. Food allergy. $\mathcal{F A M A}$ 1987;258:2886-90.

2 Serafin WE, Austen KF. Mediators of immediate hypersensitivity reactions. N Engl f Med 1987;317:30-4.

3 Stead RH, Dixon MF, Bramwell NH, et al. Mast cells are closely apposed to nerves in the human gastrointestinal mucosa Gastroenterology 1989;97:575-85.

4 MacQueen G, Marshall J, Perdue M, et al. Pavlovian conditioning of rat mucosal mast cells to secrete rat mast cell protease II. Science 1989;243:83-5.

5 Crowe SE, Soda K, Stanisz AM, et al. Intestinal permeability in allergic rats: nerve involvement in antigen induced changes. Am ₹ Physiol 1993;264:G617-23.

6 Stead RH, Tomioka M, Quinonez G, et al. Intestinal mucosal mast cells in normal and nematode-infected rat Proc Natl Acad Sci USA 1987;84:2975-9.

7 Fargeas MJ, Fioramonti J, Bueno L. Involvement of capsaicin-sensitive afferent nerves in the intestinal motor alterations induced by intestinal anaphylaxis in rats. Int Arch Allergy Immunol 1993;101:190-5.

8 Crowe SE, Sestini P, Perdue MH. Allergic reactions of rat jejunal mucosa. Ion transport responses to luminal antigen and inflammatory mediators. Gastroenterology 1990;99:74 82.

9 Regoli D, Drapeau G, Dion S, D’Orleans-Juste P. Pharmacological receptors for substance $\mathrm{P}$ and neurokinins. Life Sci 1987;40:109-17.

10 Holzer P. Local effector functions of capsaicin-sensitive sensory nerve endings: involvement of tachykinins, calcitonin gene-related peptide and other neuropeptides. Neuroscience 1988;24:739-68.

11 Hua XY, Theodorson-Norheim E, Brodin E, et al. Multiple tachykinins (neurokinin A, neuropeptide $\mathrm{K}$ and substance $\mathrm{P}$ ) in capsaicin-sensitive sensory neurons in the guinea-pig. Regul Pept 1985;13:1-19.

12 Grady EF, Baluk P, Bohm S, et al. Characterization of antisera specific to NK1, NK2, and NK3 neurokinin receptors and their utilization to localize receptors in the rat gastrointestinal tract. $\mathcal{F}$ Neurosci 1996;16:6975-86.
13 Mann PT, Southwell BR, Ding YQ, et al. Localisation of neurokinin 3 (NK3) receptor immunoreactivity in the rat neurokinin 3 (NK3) receptor immunoreactivity in
gastrointestinal tract. Cell Tissue Res 1997;289:1-9.

14 Weihe E, Nohr D, Michel S, et al. Molecular anatomy of the neuroimmune connection. Int f Neurosci 1991;59:1-23.

15 McGillis JP, Organist ML, Payan DG. Substance P and immunoregulation. Federation Proceedings 1987;46:196-9.

6 Lee HR, Ho WZ, Douglas SD. Substance P augments tumor necrosis factor release in human monocyte-derived macrophages. Clinical and Diagnostic Laboratory Immunology 1994; 1:419-23.

17 Nieber K, Baumgarten CR, Rathsack R, et al. Substance P and beta-endorphin-like immunoreactivity in lavage fluids of subjects with and without allergic asthma. $\mathcal{F}$ Allergy Clin Immunol 1992;90:646-52.

18 Shinoda $M$, Watanabe $\mathrm{N}$, Suko $\mathrm{T}$, et al. Effects of anti-allergic drugs on substance $\mathrm{P}$ (SP) and vasoactive intestinal peptide (VIP) in nasal secretions. Am $\mathcal{F}$ Rhinol 1997;11:237-41.

19 Emonds-Alt X, Doutremepuich JD, Heaulme M, et al. In vitro and in vivo biological activities of SR 140333, a novel potent non-peptide tachykinin NK1 receptor antagonist. Eur F Pharmacol 1993;250:403-13.

20 Emonds-Alt X, Vilain P, Goulaouic P, et al. A potent and selective antagonist of the neurokinin A (NK2) receptor. Life Sci 1992; 50: PL101-6.

21 Emonds-Alt X, Bichon D, Ducoux JP, et al. SR 142801, the first potent non-peptide antagonist of the tachykinin NK3 receptor. Life Sci 1995;56:PL27-32.

22 Coombs RRA, Devey ME, Anderson KJ. Refractoriness to anaphylactic shock after continuous feeding of cow's milk to guinea-pigs. Clin Exp Immunol 1978;32:263-71.

23 Di Sebastiano P, Grossi L, Angelucci D, et al. Morphologi$\mathrm{cal}$ and motor changes during experimental colitis in rats are prevented by a specific substance $\mathrm{P}$ antagonist [abstract]. Gastroenterology 1996;110:A896.

24 Julia V, Morteau O, Buéno L. Involvement of neurokinin 1 and 2 receptors in viscerosensitive response to rectal and 2 receptors in viscerosensitive response to
distension in rats. Gastroenterology 1994;107:94-102.

25 Inoue H, Nagata N, Koshihara Y. Effect of the tachykinin receptor antagonists, SR 140333, FK 888, and SR 142801, on capsaicin-induced mouse ear oedema. Inflamm Res 1996;45:303-7.

26 Perdue MH, Chung M, Gall DG. The effect of intestinal anaphylaxis on gut function in the rat. Gastroenterology 1984;86:391-7.

27 Quito FL, Brown DL. (D-ala2, met5)-enkephalinamide: CNS-mediated inhibition of prostaglandin stimulated intestinal fluid and ion transport in the rat. Peptides 1987;8: 638-46.

28 Theodorou V, Fioramonti J, Junien JL, et al. Anaphylactic colonic hypersecretion in cow's milk sensitized guinea-pigs depends upon release of interleukin-1, prostaglandins and depends upon release of interleukin-1, prostaglandins and mast cell

29 Heyman M, Andriantsoa M, Crain-Denoyelle AM, et al. Effect of oral or parenteral sensitization to cow's milk on mucosal permeability in guinea pigs. Int Arch Allergy Appl Immunol 1990;92:242-6.

30 Theodorou V, Fioramonti J, Bueno L. Recombinant interleukin-1 receptor antagonist protein prevents sensitisation and intestinal anaphylaxis in guinea-pigs. Life $\mathrm{Sci}$ 1993;53:733-8.

31 McKay DM, Berin MC, Fondacaro JD, et al. Effects of neuropeptide $\mathrm{Y}$ and substance $\mathrm{P}$ on antigen-induced ion secretion in rat jejunum. Am f Physiol 1996;271:G987-92.

32 Nylander O, Sababi M, Bark J. Characterization of ${ }^{51} \mathrm{Cr}-\mathrm{EDTA}$ as a marker of duodenal mucosal permeability. Acta Physiol Scand 1991;143:117-26.

33 Zuckerman MJ, Watts MT, Bhatt BD, et al. Intestinal permeability to ${ }^{51} \mathrm{Cr}-\mathrm{EDTA}$ in infectious diarrhea. Dig Dis permeability to ${ }^{51} \mathrm{Cr}-\mathrm{E}$

34 Jenkins RT, Chem C, Jones DB, et al. Reversibility of increased intestinal permeability to ${ }^{51} \mathrm{Cr}$-EDTA in patients with gastrointestinal inflammatory diseases. Am $\mathcal{F}$ Gastroenterol 1987;82:1159-64.

35 Ramage JK, Hunt RH, Perdue MH. Changes in intestinal permeability and epithelial differentiation during inflammation in the rat. Gut 1988;29:57-61.

36 Javed NH, Barrett KE, Wang YZ, et al. Enhanced tissue responsiveness in colonic ion transport of cow's milksensitized guinea pigs. Agents Actions 1994;41:25-31.

37 Nolte H, Schiotz PO, Kruse A, et al. Comparison of intestinal mast cell and basophil histamine release in children with food allergic reactions. Allergy 1989;44:554-65.

38 Kosecka U, Marshall JS, Crowe SE, et al. Pertussis toxin stimulates hypersensitivity and enhances nerve-mediated antigen uptake in rat intestine. Am f Physiol 1994;267: G745-53

39 Kajosaari M, Backman A, Holopainen E. Children's atopy and mastocytosis in the nasal smear. Allergy 1981;36:40510 .

40 Vercelli D, Jabara HH, Arai K, et al. Induction of human IgE synthesis requires interleukin-4 and $\mathrm{T} / \mathrm{B}$ cell interactions involving the $\mathrm{T}$ cell receptor/CD 3 complex and MHC class II antigens. F Exp Med 1989;169:1295-307.

41 Stanisz AM, Scicchitano R, Dazin P, et al. Distribution of substance $P$ receptors on murine spleen and Peyer's patch $\mathrm{T}$ and B cells. F Immunol 1987;139:749-54.

42 Stanisz AM, Befus D, Bienenstock J. Differential effects of vasoactive intestinal peptide, substance $P$, and somatostatin on immunoglobulin synthesis and proliferations by lymphocytes from Peyer's patches, mesenteric lymph nodes, and spleen. F Immunol 1986;136:152-6. 
43 Tan HP, Lebeck LK, Nehlsen-Cannarella SL. Regulatory role of cytokines in IgE-mediated allergy. 7 Leukoc Biol role of cytokines

44 Lotz M, Vaughan JH, Carson DA. Effect of neuropeptides on production of inflammatory cytokines by human monocytes. Science 1988;241:1218-21.

45 Lotz M, Jirik F, Kabouridis P, et al. B cell stimulating factor 2 interleukin- 6 is a costimulant for human thymocytes and T lymphocytes. $\mathcal{F}$ Exp Med 1988;167:1253-8

46 Aebischer I, Stampfli MR, Miescher S, et al. Neuropeptides accentuate interleukin-4 induced human immunoglobulin E synthesis in vitro. Exp Dermatol 1996;5:38-44

47 Legat FJ, Althuber P, Maier R, et al. Evidence for the presence of NK1 and NK3 receptors on cholinergic neurones in the guinea-pig ileum. Neurosci Lett 1996;207:125-8.
48 Gottwald T, Lhotak S, Stead RH. Effect of truncal vagotomy and capsaicin on mast cells and IgA-positive plasma cells in rat jejunal mucosa. Neurogastroenterol Motil 1997;9:25-32.

49 Metcalfe DD, Baram D, Mekori YA. Mast cells. Physiol Rev 1997;77:1033-79.

50 Fargeas MJ, Theodorou V, Weirich B, et al. Decrease in sensitisation rate and intestinal anaphylactic response after nitric oxide synthase inhibition in a food hypersensitivity nitric oxide synthase inhibition
model. Gut 1996;38:598-602

51 Hallgren A, Flemstrom G, Hellstrom PM, et al. Neurokinin A increases duodenal mucosal permeability, bicarbonate secretion, and fluid output in the rat. Am $\mathcal{F}$ Physiol 1997;273:G1077-86. 